\title{
Zmarł twórca bielskiej onkologii Doktor Henryk Pysz
}

Dr n. med. Henryk Pysz urodził się 15 grudnia 1931 r. w miejscowości Kozy k. Bielska-Białej, był najmłodszym z dziesięciorga rodzeństwa. Lata szkolne przypadły na okres wojenny. W 1950 r. ukończył Liceum w Pyskowicach. W latach 1950-55 studiował na Wydziale Lekarskim Śląskiej Akademii Medycznej.

Po studiach został skierowany nakazem pracy do Szpitala Powiatowego w Grotkowie na Opolszczyźnie, a następnie do Świecia nad Wisłą. W 1962 r. trafił do Instytutu Onkologii w Gliwicach, gdzie pracował do 1974 r.; tutaj uzyskał drugi stopień specjalizacji z chirurgii

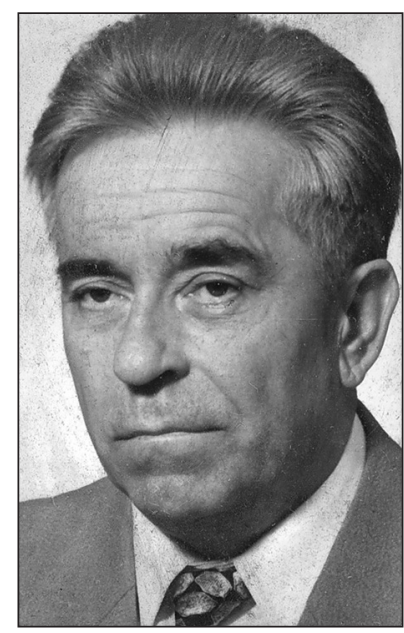

styki endoskopowej. Przy jego współudziale powstał Oddział Radio- i Chemioterapii z Zakładem Radioterapii, nieco później - Pracownia Brachyterapii. Stworzył w jednym miejscu to, co dopiero inne placówki medyczne czynią obecnie.

Dla dr. Pysza najważniejszy był pacjent, jego choroba i możliwości leczenia. Nigdy nie rezygnował z leczenia, widząc choćby najmniejszą szansę, nawet wtedy, kiedy inni wątpili w taką możliwość. Nie interesowała go przeciętność. Operował w wielkim skupieniu, bardzo starannie od początku do końca zabiegu. Dla nas, uczących się tej ogólnej i onkologicznej. W 1970 r. w Centrum Onkologii w Warszawie obronił doktorat - tematem rozprawy były „Badania nad czynnikami rokowniczymi i postępowaniem leczniczym w raku okrężnicy". Promotorem pracy był prof. Tadeusz Koszarowski.

W 1973 r. odbył miesięczny staż chirurgiczny w Ljubljanie, a w 1979 r. - dwumiesięczny w Brukseli. Praca w tym okresie wymagała od chirurga wszechstronnych umiejętności; nie było wtedy klinik narządowych i chirurg onkolog musiał umieć prawie wszystko. Zdobyte doświadczenie w chirurgii ogólnej i onkologicznej pozwalały mu na wykonywanie różnorodnych operacji.

W 1974 r. wyjechał do Opola, gdzie stworzył od podstaw Oddział Chirurgii Onkologicznej, którym kierował do 1977 r., jednak kiedy powstało województwo bielsko-bialskie, postanowił wrócić na Podbeskidzie, w swoje rodzinne strony. W Szpitalu Nr 2 w Bielsku-Białej powstała Poradnia Onkologiczna, a następnie Oddział Chirurgii Onkologicznej. Dr Pysz przez pierwsze lata, oprócz działalności chirurgicznej, prowadził i nadzorował chemioterapię. Dzięki swoim staraniom przyciągnął do Bielska wielu znakomitych specjalistów-radioterapeutów, patomorfologów, radiologów. Wiedział doskonale, że sukces w onkologii można odnieść poprzez dobrą diagnostykę patomorfologiczną i obrazową. Lecząc pacjentów ze schorzeniami onkologicznymi, widział miejsce dla oddziału chorób wewnętrznych z bazą diagnogicznych. Nauczył nas również tego, że w razie niepowodzeń w leczeniu należy brać pełną odpowiedzialność na siebie i nie szukać innych wytłumaczeń. Dr Pysz kierował się zasadą, aby chirurg był doskonale i wszechstronnie wykształcony, tak by jego umiejętności pozwalały mu wybrnąć z trudnych i niespodziewanych sytuacji, które były, są i będą się zdarzały w chirurgii. W ośrodku, który stworzył od samego początku, były konsylia lekarskie, na których podejmowano wspólnie decyzje terapeutyczne i ustalano kolejność leczenia. Po skończonej terapii pacjent pozostawał w dalszej kontroli w tym ośrodku, istniała możliwość oceny pracy i wyników zespołu leczącego i wyciągnięcia odpowiednich wniosków.

Będąc doskonale wykształconym chirurgiem, przez cały czas uczył się nowych zabiegów, które następnie wprowadzał do leczenia. Pozwalał również innym rozwijać się. Trudno wymienić zabiegi, które wykonał, ze względu na bardzo szeroki ich zakres i ilość. Wykonał kilka tysięcy operacji na przewodzie pokarmowym, piersiach płucach, tarczycy, kościach, narządzie rodnym, nerkach, wątrobie i innych. Był mistrzem w zabiegach w obrębie jelita grubego, a zwłaszcza odbytnicy (kilkaset resekcji), w zabiegach blokowych wielonarządowych, rekonstrukcyjnych głowy i szyi.

W 2000 r. przeszedł na emeryturę, ale jeszcze przez kilka lat operował i pomagał w zespole, który wykształcił, służył sztuki, były to zabiegi jakby z najlepszych atlasów chirur- 
swoim doświadczeniem i wiedzą. Sam zdecydował, kiedy zakończyć przygodę z chirurgią.

Był koneserem dobrej muzyki i sztuki, pasjonował się sportem, kochał przyrodę, wolne chwile spędzał w swoim przepięknym ogrodzie wśród kwiatów i krzewów, które sam sadził i pielęgnował.

W zawodzie lekarza pracował 50 lat. Wykształcił całe pokolenie onkologów na Podbeskidziu. Odznaczony został wieloma odznaczeniami, w tym Krzyżem Oficerskim Orderu Odrodzenia Polski i medalem „Zasłużony dla Polskiego Towrzystwa Chirurgii Onkologicznej”.

Poświęcił się bezgranicznie codziennej pracy, nie dbał o to, aby pokazywać (publikować) swoje osiągnięcia. To on stworzył ten ośrodek, spowodowałjego rozwój, ugruntował jego pozycję. Wszystko, co nastąpiło później, było tylko jego kontynuacją.
Los sprawił, że 35 lat temu po studiach trafiłem do dr. Pysza i tak dotrwaliśmy do końca. Większość tego, co osiągnąłem w swoim życiu zawodowym, zawdzięczam Jemu. Przeszedłem drogę od stażysty do ordynatora. Moim skromnym podziękowaniem za wszystko była praca doktorska oparta na materiale Jego oddziału, którą Jemu dedykowałem.

Dr Pysz był jednym z największych polskich chirurgów onkologów II połowy XX wieku. Zmarł 13 listopada 2014 r. w rodzinnej miejscowości w Kozach.

Był moim mistrzem, nauczycielem, przyjacielem, kolegą.

Dr n. med. Tadeusz Leśniak

Klinika Chirurgii Onkologicznej

Śląskiego Uniwersytetu Medycznego

w Katowicach

e-mail: tadeuszlesniak53@o2.pl 